\title{
The Effects of Biopesticide on the Antioxidant Enzyme Activities of Lemna minor
}

\author{
Muhammed Atamanalp ${ }^{1}$, Gonca Alak ${ }^{1 *}$, Özden Fakıoğlu ${ }^{2}$, Arzu Uçar ${ }^{1}$ and Veysel Parlak \\ ${ }^{1}$ Department of Aquaculture, Fisheries Faculty, Atatürk University, Turkey \\ ${ }^{2}$ Department of Basic Science, Fisheries Faculty, Atatürk University, Turkey
}

Submission: February 07, 2019; Published: February 22, 2019

Corresponding author: Gonca Alak, Department of Aquaculture, Atatürk University, Turkey

\begin{abstract}
In this study, Lemna minor which were identified as suitable plant material for ecotoxicological investigations in recent years, was exposed to different levels of bio pesticides (40-80-120 $\mu \mathrm{l} 100 \mathrm{ml}$ ), for 21 days. Treatment and control groups' plants antioxidant enzyme activities glutathione peroxidase $(G P x)$, superoxide dismutase $(S O D)$ and catalase $(C A T)$, glucose-6-phosphate dehydrogenase (G6PD) glutathione reductase (GR) glutathione-S-transferase (GST)] and malondialdehyde level (MDA) were analysed weekly (0., 7., 14, and 21. day) at during the research. The obtained data indicated that the administration doses caused changes on the antioxidant enzyme activities and even the induction effect for some enzymes ( $p<0.05)$. The inducing effects of concentrations on antioxidant enzyme activity differed from group to group. It has also been observed with low MDA levels in the subject groups that do not cause oxidative damage.
\end{abstract}

Keywords: Biopesticide; Enzyme; MDA; Aquatic plant; Antioxidant

\section{Introduction}

It has become inevitable to use pesticides in order to get more efficiency from the unit area in agricultural activities all over the world. Initially, the use of these chemicals was welcomed and later revealed that these compounds had many negative effects on the environment and human health. Pesticides can stay around for years without degradation. Pesticides that are once transmitted to the ecosystem, cause accumulation through the aquatic nutrient chain and this accumulation is increasing in the upper levels of the food chain [1]. The use of pesticides causes serious problems on human health and environment. Pesticides effect the organism by blocking cellular processes and causing changes in the cell. Some pesticides' residual effect lasts for days, weeks or months. These effects of the pesticides vary according to the chemical properties of the compound, the amount of concentration, temperature, humidity, $\mathrm{pH}$ and microorganism activities.

Increased concern about the environment and health, high consciousness on the harms of synthetic chemicals has led to intensification of studies on natural control methods of harmful livings. Biopesticides are groups of pesticides that have reduced risks compared to synthetic pesticides. Effecting in narrow area, slow moving ability and special effect shapes are the advantages of these. They are preferred since they do not make residue, remove the harmful effect without destroying the harmful living, and affect only the target harmful, limited resistant, economic, and friendly to environment and health.

Among these pesticides, azadiracthin is a natural insecticide widely used today which obtained by drying and powdering Azadirachta indica tree leaves [2]. Duckweed (Lemna minor) has been identified as a suitable plant material for ecotoxicological investigations in recent years [3-7]. Lemna absorbs its nutrients, ammonium and phosphate forms, from roots. Ammonium is an important source for duckweed. Duckweed is preferred because of its rapid growth rate, low fiber and high protein content. It is also used to increase water quality in different water reserves. Obermeier et al. [8] reported that Lemna sp. might be used for phytoremediation of low-level contamination with metals and organic xenobiotics. But some authors recommend a more detailed analysis of the development of the oxidative burst following copper exposure and of the enzymatic metabolism of pethoxamide in order to elucidate the extent of its removal from water. Under abiotic stress conditions, highly toxic and reactive molecules called reactive oxygen species (ROS) are formed in plants. These molecules disrupt the structure of proteins, lipid carbohydrates and DNA, leading to the formation of oxidative stress. The plants have antioxidant defense systems to prevent this damage, this study was planned and conducted 
to investigate the effects of azadirachtin on antioxidant defense systems of biopesticides on duckweed (L. minor).

\section{Materials and Method}

\section{Aquatic Plant used in the experiment}

The duckweeds are found intensive in the basins of the Pulur, Karasu and Tortum streams in the Erzurum city borders. The plants are collected fresh from these areas and transferred to the Atatürk University Faculty of Fisheries. Plant adaptation was provided in suitable aquariums at Algae Unit of faculty.

\section{Biopesticide used in the experiment}

azadiracthin, which is used as biopesticide, was obtained from commercial company and applied by considering the renewable static test method in 12 hours according to NOEL value.

\section{Trial Design}

The adapted for 4 weeks duckweeds were divided into four groups, a control group and 3 different doses of biopesticide. Three different concentrations of 40-80-120 $\mu$ l of stock solution were applied to $100 \mathrm{ml}$ test medium. Weekly $(7,14$. and 21. days) samples were made during the 21-day trial.

\section{Preparing Homogenate for Antioxidant Enzyme Activ- ity Measurements}

The samples were placed in a porcelain mortar and thoroughly crushed with a hammer, and a small amount of liquid nitrogen was added and obtained fine powder. Then $\mathrm{KH}_{2} \mathrm{PO}_{4}$ buffer solution was added to the samples, the homogenates were centrifuged at $15.000 \mathrm{~g}$ at 15 minute $4{ }^{\circ} \mathrm{C}$ and removed from the centrifuge tube [9]. After centrifugation, the supernatant fraction was obtained, and enzyme activities were directly measured via this supernatant.

\section{Activity Measurements of Glucose 6-Fosfat Dehydro- genase (G6PD) Enzyme}

Nicotinamidadenin dinucleotidephosphate (NADP+) is reduced by glucose 6-phosphate dehydrogenase in the presence of glucose 6-phosphate. The formation rate of NADPH is dependent on glucose 6-phosphate dehydrogenase activity and can be measured by an increase in absorbance at $340 \mathrm{~nm}$ [10].

\section{Activity Measurements of Glutathione Reductase (GR) Enzyme}

In determining the activity of the glutathione reductase enzyme, reduction of the NAD (P) H of the GR enzyme involved in the reaction medium has been taken into consideration.

\section{Superoxide Dismutase (SOD) Activity Measurement}

This analysis is based on the reaction of the produced superoxide radicals with NBT. The formation of the absorbing at $560 \mathrm{~nm}$ is considered [11].

\section{Catalase (CAT) Activity Measurement}

The activity analyses are based on the measurement of the absorbance reduction at $240 \mathrm{~nm}$ when $\mathrm{H}_{2} \mathrm{O}_{2}$ in the measurement medium is converted to $\mathrm{H}_{2} \mathrm{O}$ by CAT [12].

\section{Activity Measurements of Glutathione Peroxidase (GPx)}

The absorbance reductions at $340 \mathrm{~nm}$ of the NADPH concentration, which is active at the conversion of GSH-Pxcatalyzed GSSG to glutathione reductase (GSSG-Rd) catalyzed GSH conversion, are monitored for 2 minutes [10].

\section{Glutathione S-Transferase Activity Measurement}

This enzyme catalyzes the reaction of the glutathione group with CDNB. It gives absorbance at $340 \mathrm{~nm}$ and is calculated by optical density change [13]. Protein levels of each sample were determined bovine serum albumin (BSA) as the standard [14].

\section{Lipid Peroxidation (MDA) Measurement}

The fatty acids are read at $532 \mathrm{~nm}$ considering the colored form of thiobarbituric acid in the determination of molondialdehyde from the peroxidation products of reaction with free radicals [15].

\section{Statistical Analyses}

The data obtained from the enzyme activity measurements are given as mean \pm standard deviation. $(n=9)$. The findings were subjected to analysis of variance (ANOVA) and averages were compared using Duncan's multiple comparison test. The importance level is taken as 0.05 .

\section{Results and Discussion}

Table 1: Lemna minor enzyme activities and MDA level effected of different levels biopesticide application

\begin{tabular}{|c|c|c|c|c|c|c|c|c|}
\hline \multirow{2}{*}{ Day } & \multirow{2}{*}{ Group } & \multicolumn{6}{|c|}{ Parameters } \\
\cline { 3 - 9 } & & SOD* & CAT $^{*}$ & GPX $^{*}$ & GR $^{\text {Ns }}$ & GST $^{\text {Ns }}$ & G6PD* $^{*}$ & MDA $^{*}$ \\
\hline \multirow{2}{*}{0} & $40 \mu \mathrm{l}$ & $0,26 \pm 0,00^{\mathrm{b}}$ & $0,56 \pm 0,00^{\mathrm{b}}$ & $0,12 \pm 0,00^{\mathrm{b}}$ & $0,67 \pm 0,00^{\mathrm{a}}$ & $0,55 \pm 0,00^{\mathrm{a}}$ & $0,08 \pm 0,00^{\mathrm{a}}$ & $0,67 \pm 0,00^{\mathrm{a}}$ \\
\cline { 2 - 9 } & $80 \mu \mathrm{l}$ & $0,26 \pm 0,00^{\mathrm{b}}$ & $0,56 \pm 0,00^{\mathrm{b}}$ & $0,12 \pm 0,00^{\mathrm{b}}$ & $0,67 \pm 0,00^{\mathrm{a}}$ & $0,55 \pm 0,00^{\mathrm{a}}$ & $0,08 \pm 0,00^{\mathrm{a}}$ & $0,67 \pm 0,00^{\mathrm{a}}$ \\
\cline { 2 - 10 } & $120 \mu \mathrm{l}$ & $0,26 \pm 0,00^{\mathrm{b}}$ & $0,56 \pm 0,00^{\mathrm{b}}$ & $0,12 \pm 0,00^{\mathrm{b}}$ & $0,67 \pm 0,00^{\mathrm{a}}$ & $0,55 \pm 0,00^{\mathrm{a}}$ & $0,08 \pm 0,00^{\mathrm{a}}$ & $0,67 \pm 0,00^{\mathrm{a}}$ \\
\hline
\end{tabular}




\section{Oceanography \& Fisheries Open access Journal}

\begin{tabular}{|c|c|c|c|c|c|c|c|c|}
\hline \multirow{2}{*}{7} & $40 \mu \mathrm{l}$ & $0,32 \pm 0,03^{\mathrm{a}}$ & $0,16 \pm 0,03^{\mathrm{ab}}$ & $0,13 \pm 0,04^{\mathrm{b}}$ & $0,63 \pm 0,03^{\mathrm{a}}$ & $0,24 \pm 0,01^{\mathrm{a}}$ & $0,06 \pm 0,00^{\mathrm{b}}$ & $0,16 \pm 0,09^{\mathrm{bc}}$ \\
\cline { 2 - 8 } & $80 \mu \mathrm{l}$ & $0,44 \pm 0,01^{\mathrm{a}}$ & $0,99 \pm 0,01^{\mathrm{b}}$ & $0,61 \pm 0,04^{\mathrm{ab}}$ & $0,58 \pm 0,03^{\mathrm{a}}$ & $0,37 \pm 0,09^{\mathrm{a}}$ & $0,02 \pm 0,00^{\mathrm{c}}$ & $0,09 \pm 0,02^{\mathrm{c}}$ \\
\cline { 2 - 9 } & $120 \mu \mathrm{l}$ & $1,06 \pm 0,02^{\mathrm{a}}$ & $0,70 \pm 0,07^{\mathrm{b}}$ & $0,75 \pm 0,05^{\mathrm{a}}$ & $0,59 \pm 0,05^{\mathrm{a}}$ & $0,99 \pm 0,07^{\mathrm{a}}$ & $0,04 \pm 0,00^{\mathrm{bc}}$ & $0,42 \pm 0,01^{\mathrm{b}}$ \\
\hline \multirow{3}{*}{14} & $40 \mu \mathrm{l}$ & $1,17 \pm 0,08^{\mathrm{a}}$ & $0,40 \pm 0,02^{\mathrm{ab}}$ & $0,51 \pm 0,02^{\mathrm{b}}$ & $0,63 \pm 0,03^{\mathrm{a}}$ & $0,63 \pm 0,02^{\mathrm{a}}$ & $0,05 \pm 0,00^{\mathrm{b}}$ & $0,24 \pm 0,07^{\mathrm{bc}}$ \\
\cline { 2 - 9 } & $80 \mu \mathrm{l}$ & $1,13 \pm 0,05^{\mathrm{a}}$ & $0,68 \pm 0,02^{\mathrm{b}}$ & $0,31 \pm 0,01^{\mathrm{ab}}$ & $0,65 \pm 0,02^{\mathrm{a}}$ & $0,52 \pm 0,02^{\mathrm{a}}$ & $0,01 \pm 0,00^{\mathrm{c}}$ & $0,08 \pm 0,01^{\mathrm{c}}$ \\
\hline & $120 \mu \mathrm{l}$ & $0,81 \pm 0,04^{\mathrm{a}}$ & $0,61 \pm 0,02^{\mathrm{b}}$ & $0,32 \pm 0,02^{\mathrm{a}}$ & $0,88 \pm 0,08^{\mathrm{a}}$ & $0,35 \pm 0,09^{\mathrm{a}}$ & $0,02 \pm 0,00^{\mathrm{bc}}$ & $0,16 \pm 0,03^{\mathrm{b}}$ \\
\hline \multirow{2}{*}{21} & $40 \mu \mathrm{l}$ & $0,96 \pm 0,01^{\mathrm{a}}$ & $0,46 \pm 0,01^{\mathrm{ab}}$ & $0,29 \pm 0,05^{\mathrm{b}}$ & $0,70 \pm 0,02^{\mathrm{a}}$ & $0,38 \pm 0,01^{\mathrm{a}}$ & $0,02 \pm 0,00^{\mathrm{b}}$ & $0,18 \pm 0,03^{\mathrm{bc}}$ \\
\cline { 2 - 9 } & $80 \mu \mathrm{l}$ & $0,42 \pm 0,02^{\mathrm{a}}$ & $0,63 \pm 0,09^{\mathrm{b}}$ & $0,16 \pm 0,00^{\mathrm{ab}}$ & $0,81 \pm 0,03^{\mathrm{a}}$ & $0,32 \pm 0,07^{\mathrm{a}}$ & $0,01 \pm 0,00^{\mathrm{c}}$ & $0,23 \pm 0,01^{\mathrm{c}}$ \\
\hline & $120 \mu \mathrm{l}$ & $0,77 \pm 0,03^{\mathrm{a}}$ & $0,34 \pm 0,02^{\mathrm{b}}$ & $0,63 \pm 0,04^{\mathrm{a}}$ & $0,54 \pm 0,07^{\mathrm{a}}$ & $0,34 \pm 0,03^{\mathrm{a}}$ & $0,02 \pm 0,00^{\mathrm{bc}}$ & $0,11 \pm 0,01^{\mathrm{b}}$ \\
\hline
\end{tabular}

a, b: There is no statistical difference between the averages, indicated by the same letter in the same column. ${ }^{*} p<0.05$, NS: Not Significant, Specific enzyme activities EU/mg protein, MDA is calculated as $\mathrm{nmol} / \mathrm{ml}$.

Antioxidant enzyme activities and MDA levels of treatment groups at the end of chronic treatment are given in Table 1. In the present study, different values were determined for all the treatment groups in terms of enzyme activity compared to the control. Different concentration applications showed an inducing effect on antioxidant enzyme activity and not causing oxidative damage was surveyed with low MDA levels in the corresponding groups. In terms of all the parameters examined, the statistical difference between control and treatment groups was found to be significant $(\mathrm{p}<0.05)$. Antioxidant enzymes have a vital prescription in the regulation of cell balance. Inductions are a consequence of the response to contaminants, and antioxidant enzyme activities and lipid peroxidation are important indicators of cell damage in toxicological studies [2,16-19].

The presence of an oxygen-rich atmosphere ensured the development of an endogenous antioxidant system that counteracts reactive oxygen species (ROS) and reactive nitrogen species (RNS) (20). This reduction of $\mathrm{O}_{2}$ metabolism products is controlled by the enzymatic (SOD), (CAT) and (GSH-Px) cellular defense mechanisms [21-23]. Biopesticide application generally resulted in an increase in duckweed CAT-specific activity and higher values were obtained than the control. There was a decrease in CAT activity in the $40 \mu \mathrm{L}$ concentrations group. It can be interpreted that these changes may occur in cases where adaptation cannot be achieved and with high $\mathrm{H}_{2} \mathrm{O}_{2}$. It can also be assumed that the decline in CAT activity is due to the suppression of protein synthesis by free radicals [24].

Some enzymes are defined as "catalytically perfect" or "kinetically excellent". Examples of such enzymes include triosephosphate isomerase, carbonic anhydrase, acetylcholinesterase, catalase, b-lactamase and superoxide dismutase. When the production of $\mathrm{O}_{2}^{-}$anion is high in the cells, the induction of the SOD enzyme takes place and the $\mathrm{O}_{2}$-anion is converted to $\mathrm{H}_{2} \mathrm{O}_{2}$. That's why; the increase in SOD activity is a result of increased $\mathrm{O}_{2}^{-}$production. Because of the catalytic activity of many enzymes, such as dehydrogenases and oxidases, and the oxidation of many biomolecules in thiols that take place in aerobic environments, $\mathrm{O}_{2}^{-}$anion is formed [25]. Glutathione peroxidase transfers the electrons of GSH used as a substrate in the presence of $\mathrm{H}_{2} \mathrm{O}_{2}$ to $\mathrm{H}_{2} \mathrm{O}_{2}$ and catalyzes the oxidation of GSH to GSSG. GPx activity increased in treatment groups compared to control. With this increase, we are thinking that oxidative stress may be induced by increasing GSSG amount, GSH / GSSG ratio and GPx activity. Again, in order to increase the oxidative toxicity resistance, it can be said that the increase in the enzyme activity occurs [2,18-19,26-27].

It is thought that in the Lemna minor affected by biopesticide, decreasing GSH level in the first few days with GSH / GSSG increasing in the next few days may be associated with newly established GSH balance or other detoxification mechanisms. It is estimated that increases in GSH levels in all time are due to an adaptive response to oxidative stress. In addition, the inability to observe significant changes in GR activity in all groups may be due to extracellular transport of GSSG in place of GSH to inhibit its cytotoxic effects. The increases in GSH level under the pollutant effect are explained by the regulation and activations that the enzymes involved in GSH synthesis can carry out to replace the GSH level $[26,27]$. In this study, it is thought that the decrease of GST in the pesticide-treated groups, comparison with the control is due to the increase of $\mathrm{O}_{2}$ [28]. High dose administration has severely reduced GST activity. It is known that this may be due to changes in antioxidant enzymes according to different species and tissues in response to oxidative stress [29].

GSH antioxidant defense mechanism and NADP synthesized in the pentose phosphate metabolic pathway in which G6PD and 6PGD coexist are used to produce the enzymes in this mechanism. The importance of G6PD and 6PGD in metabolism has been known for many years. GSH antioxidant defense 
mechanism and NADP synthesized in the pentose phosphate metabolic pathway in which G6PD and 6PGD coexist are used to produce the enzymes in this mechanism. Therefore, G6PD and 6PGD are thought to be antioxidant enzymes G6PD and 6PGD enzymes have been found to decrease significantly in fish which effected by pollution. This is since these enzymes are the first enzymes of the pentose phosphate pathway and that the increase or decrease in these enzymes is not only due to exposure to pollutants but also because these enzymes are potential targets of toxic chemicals [30].

In this study, different concentrations of azadiracthin resulted in a decrease in G6PD activity. In this process, biopesticides cause $\mathrm{O}_{2}$ production and inhibition in enzyme activity [31]. When lipid hydroperoxides resulting from lipid peroxidation break down, most biologically active aldehydes form. These compounds are either metabolized at the cell level or diffuse from the baseline domains and radiate damage to other parts of the cell. Malondialdehyde (MDA), measurable with thiobarbutyric acid, is used to determine these damages. MDA is not a specific or quantitative indicator of fatty acid oxidation but correlates well with the degree of lipid peroxidation $[2,18]$.

It has reported that the enzyme GSH-Px inhibits lipid peroxidation primarily by protecting the damaged cell, peroxypolyanionic fatty acids, short chain fatty acids, and GSH-Px enzymes using GSH instead of MDA production into hydroxyl fatty acids [32]. Based on the results obtained from the study, it has become necessary to regularly monitor the pollution in natural water environments, to determine the effects on livings, to establish a database with these studies, and to determine the impact levels of pollutants harmful for aquaculture.

\section{Acknowledgement}

We would like to thank Atatürk University Scientific Research Projects Unit and the Faculty of Fisheries for their support for our project (BAP 2016/222).

\section{References}

1. Pournourmohammadi S, Farzami B, Azizi OSN, Abdollahi EM (2005) Efffect of malathion subchronic exposure on rat skeletal muscle glucose metabolism. Environ Toxicol Pharmacol 19(1): 191-196.

2. Alak G, Ucar A, Parlak V, Yeltekin AÇ, Tas IH, et al. (2017a) Assessment of 8-hydroxy-2-deoxyguanosine activity, gene expression and antioxidant enzyme activity on rainbow trout (Oncorhynchus mykiss) tissue exposed to biopesticide. Comparative Biochemistry and Physiology Part C: Toxicology \& Pharmacology 203: 51-58.

3. Appenroth K, Krech K, Keresztes A, Fischer W, Koloczek H (2010) Effects of nickel on the chloroplasts of the duckweeds Spirodela ployrhiza and Lemna minor and their possible use biomonitoring and phytoremediation. Chemosphere 78(3): 216-233.

4. Leblebici Z, Aksoy A (2011) Growth and lead accumulation capacity of Lemna minor and Spirodela polyrhiza (Lemnaceae): Interactions with nutrient enrichment. Water Air Soil Pollut 214(1-4): 175-184.

5. Mechora S, Stibilj V, Germ M (2015) Response of ducweed to varios concentrations of selenite. Enviro Sci Pollut Res Int 22(4): 2416-2422.
6. Song L, Vijver M, Peijnenburg WJGM (2015) Comparative toxicity of copper nanoparticles across three Lemnaceae species. Sci Total Environ 518(519): 217-224.

7. Fakığlu Ö, Atamanalp M (2017) Effects of glyposate on starch accumulation, chlorophyll and enzyme activity of duckweed (Lemna minor L). Acta Aquatica Turcica 13(1): 32-41.

8. Obermeier M, Schröder CA, Helmreich B, Schröder P (2015) The enzymatic and antioxidative stress response of Lemna minor to copper and a chloroacetamide herbicide. Environ Sci Pollut Res Int. 22(23): 18495-18507.

9. Hou W, Chen X, Song G, Wang Q Chi Chang C (2007) Effects of copper and cadmium on heavy metal polluted waterbody restoration by duckweed (Lemna minor). Plant Physiol Biochem. 45(1):62-69.

10. Beutler E (1984) Red Cell Metabolism: A Manual of Biochemical Methods. In: ( $2^{\text {nd }}$ edn) Gruneand Starton, New York, USA.

11. Sun Y, Oberley LW, Ying L (1988) A simple method for clinical assay of superoxide dismutase. Clin Chem, 34(3): 497-500.

12. Aebi H (1974) Catalase. In: Bergmeyer HU (Ed). Methods of Enzymatic Analysis, Academic Press, USA, pp.673-678.

13. Habig WH, Pabst MJ, Jakoby WB (1974) Glutathione s-transferases. The first enzymatic step in mercapturic acid formation. J BiolChem 249(25): 7130-7139.

14. Bradford MM (1976) A rapid and sensetive method fort he quantitation of microgram quantities of protein utilizing the principle of proteindye binding. Analytical Biochemistry 77(1-2): 248-251.

15. Luo Y, Su Y, Lin RZ, Shi HH, Wang XR (2006) 2-chlorophenol induced ROS generation in fish Carassius auratus based on the EPR method. Chemosphere 65(6): 1064-1073.

16. Alak G, Atamanalp M, Topal A, Arslan H, Kocaman EM, (2013a) Effect of sub-lethal lead toxicity on the histopathological and antioxidant enzyme activity of rainbow trout (Onchorynchus mykiss). Fresenius Environmental Bulletin 22(3): 733-738.

17. Alak G, Atamanalp M, Topal A, Arslan H, Altun S (2013b) Histopathological and biochemical effect of humic acid against cadmium toxicity in brown trout gills and muscle. Turkish Journal of Fisheries and Aquatıc Sciences 13: 315-320.

18. Alak G,Yeltekin AC, Tas IH, Ucar A, Parlak V, et al. (2017) Investigation of 8-OHdG, CYP1A, HSP70 and transcriptional analyses of antioxidant defence system in liver tissues of rainbow trout exposed to eprinomectin. Fish Shellfish Immunol 65: 136-144.

19. Alak G, Ucar A, Yeltekin AÇ, Comaklı S, Parlak V, et al. (2018) Neuroprotective effects of dietary borax in the brain tissue of rainbow trout (Oncorhynchus mykiss) exposed to copper-induced toxicity. Fish Physiol Biochem 44(5): 1409-1420.

20. Sen CK, Packer L, Hanninen O (2000) Handbook of Oxidants and Antioxidants in Exercise. In: Amsterdam, Elsevier, USA.

21. Wickens AP (2001) Ageing and free radical theory. Respiration Physiology 128: 379-391.

22. Wohaieb SA, Godin DV (1987) Starvation related alterations in free radical tissue defense mechanisms in rats. Diabetes 36(2): 169-173.

23. Uçar A, Ali Al-Hamdani AH, Alak G, Atamanalp M, Topal A, et al. (2012) Effects of Carboxin on Superoxide Dismutase Enzyme Activite in Rainbow trout (Oncorhynchus mykiss). BIBAD Research Journal of Biological Sciences 5(2): 083-085.

24. Palaniappan PR, Vijayasundaram V (2008) FTIR study of arsenic induced biochemical changes on the liver tissues of fresh water fingerlings Labeo Rohita. Romanian J Biophys 18: 135-144. 
25. Bernabucci U, Ronchi B, Lacetera N, Nardone A (2002) Markers of oxidative status in plasma and erythrocytes of transition dairy cows during hot season. J Dairy Sci 85(9):2173-2179.

26. Murphy TH, Miyamoto M, Sastre A, Schnaar RL, Coyle JT (1989) Glutamate toxicity in a neuronal cell line involves inhibition of cystine transport leading to oxidative stress. Neuron 2(6):1547-1558.

27. Szkudelski T (2001) The mechanism of alloxan and streptozotocin action in b cells of the rat pancreas. Physiol Res 50(6): 537-546.

28. Matkovics B, Witas H, Gabrielak T, Szabo L (1987) Paraquat as an agent affecting antioxidant enzymes of common carp erythrocytes. Comp Biochem Physiol 87(1): 217-219.

29. Ahmad F, Al SS, Shakoori A (1995) Sublethal effects of danitol fenpropathrin'a synthetic pyrethroid, on preshwater chinese grass carp, Ctenopharyngodon idella. Folia Biol (Krakow) 43: 151-159.
30. Reiter R, Tang , Garcia JJ, Munoz Hoyos A(1997) Pharmacological actions of melatonin in oxygen radical pathophysiology. Life Sci 60(25):2255-2271.

31. Topal A, Atamanalp M, Oruç E, Kırıcı M, Kocaman EM (2014) Apoptotic effects and glucose-6-phosphate dehydrogenase responses in liver and gill tissues of rainbow trout treated with chlorpyrifos. Tissue and cell 46(6): 490-496.

32. Nazıroğlu M, Güler M, Özgül C, Saydam G, Küçükayaz M, et al. (2014) Apple cider vinegar modulates serum lipid profile, erythrocyte, kidney, and liver membrane oxidative stress in ovariectomized mice fed high cholesterol. J Membr Biol 247(8): 667-673.

\section{Your next submission with Juniper Publishers will reach you the below assets}

- Quality Editorial service

- Swift Peer Review

- Reprints availability

- E-prints Service

- Manuscript Podcast for convenient understanding

- Global attainment for your research

- Manuscript accessibility in different formats

( Pdf, E-pub, Full Text, Audio)

- Unceasing customer service

Track the below URL for one-step submission https://juniperpublishers.com/online-submission.php 